\title{
Seasonality of water supply network failure in the aspect of water supply safety
}

\author{
Izabela Piegdon ${ }^{1, *}$, and Barbara Tchórzewska-Cieślak ${ }^{1}$ \\ ${ }^{1}$ Rzeszow University of Technology, The Faculty of Civil and Environmental Engineering and \\ Architecture, Department of Water Supply and Sewage Systems, \\ al. Powstańców Warszawy 12, 35-959 Rzeszów
}

\begin{abstract}
Many phenomena are characterized by unevenness and variability in time, so-called periodic fluctuations, of which seasonal variations are a special case. In water supply systems, the failures of water pipes are also characterized by unevenness during the year. Seasonality is especially evident when the failures are analysed at particular times of the year. The main purpose of this paper is to present the problems of failures in water supply network caused by seasonal changes, to determine seasonal indicators and to give an example of the system failure analysis for the selected city of south-eastern Poland. The analysis was based on actual operational data obtained from water supply company.
\end{abstract}

\section{Introduction}

For several years in Poland great importance is attached to critical infrastructure and its security. Polish legislation aimed at the protection of critical infrastructure is, primarily, the Act of 26 April 2007 on Crisis Management (Dz. U. z 2007r. Nr 89, poz. 590) [1]. The definition of critical infrastructure (CI) has been clearly shown in the mentioned above Act. $\mathrm{CI}$ is understood as systems and contained in them objects, of key importance for the security of the state and its citizens, as well as serving to ensure efficient functioning of public administration authorities, institutions and enterprises. According to this provision, critical infrastructure includes the following systems: energy, fuel and energy resources supply systems, communication systems, tele-information network systems, financial systems, food supply systems, water supply systems, health protection systems, transportation systems, rescue systems, systems ensuring the continuity of public administration activities, systems of production, storing and use of chemical and radioactive substances, including pipelines for dangerous substances. (Art. 3 point 2) [1]. Safety of functioning of water distribution subsystem belonging to CI is ensured when the safety requirements given in legislation and standards are applied. Legal regulations for water distribution subsystem are, primarily, the Act on collective water supply and sewage disposal [2] and Regulation of the Minister of Health on the quality of water for human consumption [3]. The water distribution subsystem (WDS) consists of water-pipe network (main, distributive and house connections) together with the specific fittings (gate valves,

\footnotetext{
*Corresponding author: piegi@prz.edu.pl
} 
check valves, hydrants, drainage, aeration, flow meters). The objective reality in WDS functioning is the possibility that various failures can occur. They can cause losses of water, breaks in water supply, as well as they can be a reason of the so called secondary water contamination in water-pipe network, which is a serious threat to consumers safety.

According to the standards given by the World Health Organization (WHO) [4, 5] drinking water should not only fulfil the consumers safety criteria but also meet the organoleptic requirements, however, from technical requirements point of view, it should be supplied to consumers in a suitable amount and with a suitable pressure. Thus the basic definitions of operational reliability and safety reliability of subsystems were assumed [6-16]:

- operational reliability (OR) of the WDS is the ability to supply a constant flow of water for various groups of consumers, with a required amount, specific quality and specific pressure, according to the users requirements in the specific operational conditions, at any time (then we use the availability indicator $\mathrm{K}$ ) or in the specific time range (then we use reliability function $\mathrm{R}(\mathrm{t})$ ).

- safety reliability (SR) of the WDS means the ability of the system to safely execute its functions in a given environment. The measure of safety reliability is the probability of lack of the undesirable catastrophic consequences (loss of health or human lives, serious material losses or losses in the natural environment).

Reliability analysis of the WSS treated as an integral whole is, in practice, very difficult and labour consuming because it requires a lot of detailed information concerning particular subsystems and their elements, as well as an analysis of failure dependence (sometimes failure in one subsystem can cause failure of the next one, the so called domino effect [17]). The main purpose of this paper is to present the problems of failures in water supply network caused by seasonal changes, to determine seasonal indicators and to give an example of the system failure analysis for the selected city of south-eastern Poland.

\section{Research methodology}

Due to a specific character of water-pipe network operation, the system of failure repair is inseparably connected with the maintenance of network operational reliability and a priority is to provide consumers with suitable quality of water. As far as water-pipe network is concerned, water supply companies have a documented database of failures, but the database contains only the final data which do not identify the primary causes of failures. We can answer the question what kind of failure took place, e.g. corrosion, transverse crack, longitudinal crack, but it is much more difficult to identify the cause of failure.

It has been shown in the publications that the failure rate of water pipes is influenced by many factors, e.g. ground instability, pipe age, function of the pipe (transit, main, distribution and house connections), water pressure in the network, flow rate, ground corrosivity, groundwater corrosivity, material of pipe and related with it method of joining the pipes. Operational researches also show the impact of the season and the associated with it air, ground and water in the network temperature on the failure rate of pipes [18-27]. It should be remembered that water-pipe network works with the changeable pressure and flow parameters which is connected, mainly, with a change in an amount of water used by consumers over time. The important problem that occurs in many urban water-pipe networks is also a considerable oversizing of the network, which causes drop in water flow speed, water-pipes silting up and, as a consequence, the unfavourable flow conditions that can cause the deterioration of water quality in water-pipe network [28, 29].

Many phenomena are characterized by unevenness and variability in time, then we are talking about the so-called periodic fluctuations, of which seasonal variations are a special case. As the literature shows, the failure rate of water pipes is also characterized by 
unevenness during the year, which is particularly seen when analysing the failure rate at particular seasons of the year. Taking the above into account, an attempt was made to examine seasonal variations when failures arise in the water supply network. A simple method of separating seasonal fluctuations is a method based on the average homonymous periods the formula (1) was used to determine the seasonal index $S_{i}$.

$$
\begin{aligned}
& S_{i}=\frac{\overline{y_{i}} \cdot d}{\sum_{i=1}^{d} \overline{y_{i}}} \cdot 100, \\
& \overline{y_{i}}=\frac{\sum_{i=1}^{4} k_{i}}{d},
\end{aligned}
$$

where:

$S_{i}$ - the seasonal index for the i-th sub-period,

$y_{i}$ - the arithmetic mean of the size of the studied phenomenon in homonymous sub-periods (January, February, ..., December) in years 2008-2016,

$d$ - number of homonymous sub-periods (number of months),

$k_{i}$ - number of failures in a given year and month.

The absolute levels of seasonal fluctuations for individual sub-periods are calculated using formula (3).

where:

$$
g_{i}=S_{i} \cdot \bar{y}-\bar{y}
$$

$g_{i}$ - the absolute levels of seasonal fluctuations expressed in the same units as the studied phenomenon.

To determine the average value of the studied phenomenon, the formula (4) was used.

$$
\bar{y}=\frac{\sum \bar{y}_{i}}{12}
$$

where:

$\overline{-}-$ the average value of the studied phenomenon.

\section{Research object}

The analysed water supply network consists of a main network made of cast iron and steel pipes with a total length of $54.9 \mathrm{~km}$ and a distribution network with a length of $586.5 \mathrm{~km}$ made of cast iron, steel, PE and PVC. The total length of the network with connections is $1006.6 \mathrm{~km}$ (in 2017). The source of data was the operational documentation regarding failures in the water supply network given by the water supply company. The data set contained the following information: date of failure notification, street where the failure occurred, material and diameter of the damaged pipe, cause of failure, repair time, date of failure removal, type of pipe. 


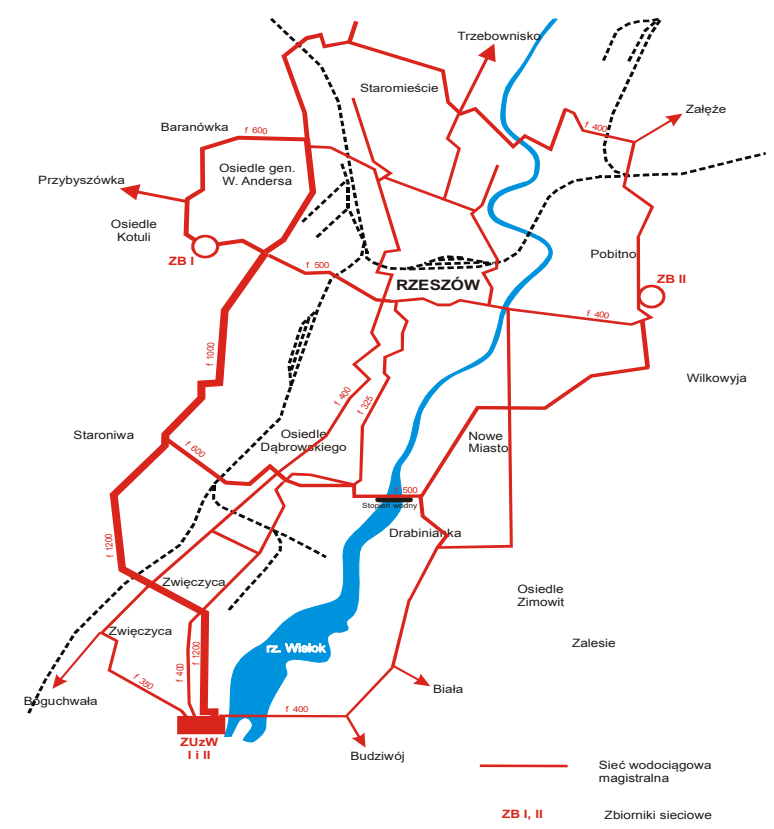

Fig. 1. Scheme of analysed water supply network.

To determine the seasonality of water supply failure, the network failure rate was used. These data are presented in Table 1 .

Table 1. List of the number of failures of the water supply network divided into the main and distribution network with house connections in the years 2008-2016 (own study).

\begin{tabular}{|c|c|c|c|c|c|c|}
\hline \multirow[b]{3}{*}{ Years } & \multicolumn{4}{|c|}{ Type of network } & \multirow{2}{*}{\multicolumn{2}{|c|}{$\begin{array}{c}\text { House } \\
\text { connections }\end{array}$}} \\
\hline & \multicolumn{2}{|c|}{ Main } & \multicolumn{2}{|c|}{ Distribution } & & \\
\hline & $\begin{array}{c}\text { length } \\
(\mathrm{km})\end{array}$ & $\begin{array}{c}\text { number } \\
\text { of } \\
\text { failure }\end{array}$ & $\begin{array}{l}\text { length } \\
(\mathrm{km})\end{array}$ & $\begin{array}{c}\text { number } \\
\text { of } \\
\text { failure }\end{array}$ & $\begin{array}{c}\text { length } \\
(\mathrm{km})\end{array}$ & $\begin{array}{c}\text { number } \\
\text { of } \\
\text { failure }\end{array}$ \\
\hline 2008 & 49.5 & 21 & 447.7 & 81 & 322.8 & 116 \\
\hline 2009 & 49.8 & 32 & 468 & 72 & 323.2 & 113 \\
\hline 2010 & 49.8 & 35 & 490.5 & 96 & 323.8 & 124 \\
\hline 2011 & 49.8 & 45 & 504.1 & 92 & 323.8 & 162 \\
\hline 2012 & 49.8 & 44 & 520.5 & 95 & 323.8 & 144 \\
\hline 2013 & 49.8 & 24 & 524.8 & 103 & 324 & 131 \\
\hline 2014 & 49.8 & 33 & 530 & 69 & 324 & 122 \\
\hline 2015 & 49.8 & 48 & 540.4 & 103 & 324.3 & 191 \\
\hline 2016 & 54.9 & 32 & 586.5 & 89 & 365.2 & 118 \\
\hline
\end{tabular}

\section{Results}

On the basis of the performed analysis of network failure rate, the network failure rate seasonality analysis was performed. The analysis was carried out for the whole network and house connections. The seasonal indices for individual operational years were determined 
and the absolute fluctuation levels were calculated for individual sub-periods (months). The number of failures has been compiled and presented in Table 2.

Table 2. The relative and absolute seasonal fluctuations for water supply network and house connections in the years 2008-2016 (own work).

\begin{tabular}{|c|c|c|c|c|c|c|c|c|c|c|c|c|}
\hline \multirow[b]{2}{*}{$\begin{array}{c}\text { Years } \\
2008-2017\end{array}$} & \multicolumn{12}{|c|}{ Month } \\
\hline & 导 & 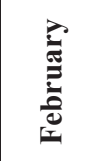 & 竞 & $\frac{\bar{\Xi}}{4}$ & $\sum^{\vec{J}}$ & $\stackrel{\Xi}{\Xi}$ & 를 & 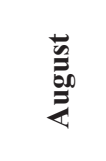 & 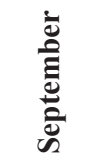 & 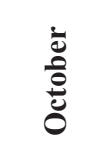 & $\begin{array}{l}\dot{\Xi} \\
\overline{0} \\
\bar{\Xi} \\
\dot{z} \\
z\end{array}$ & 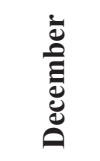 \\
\hline$y_{i}$ & 23.30 & 17.40 & 15.40 & 13.00 & 12.40 & 13.90 & 17.20 & 22.70 & 19.10 & 22.80 & 24.70 & 31.50 \\
\hline$S_{i}$ & 119.79 & 89.46 & 79.18 & 66.84 & 63.75 & 71.47 & 88.43 & 116.71 & 98.20 & 117.22 & 126.99 & 161.95 \\
\hline$g_{i}$ & 3.85 & -2.05 & -4.05 & -6.45 & -7.05 & -5.55 & -2.25 & 3.25 & -0.35 & 3.35 & 5.25 & 12.05 \\
\hline
\end{tabular}

Figure 2 presents the distribution of the number of failures in the analysed years (2008-2016), detailing the months.

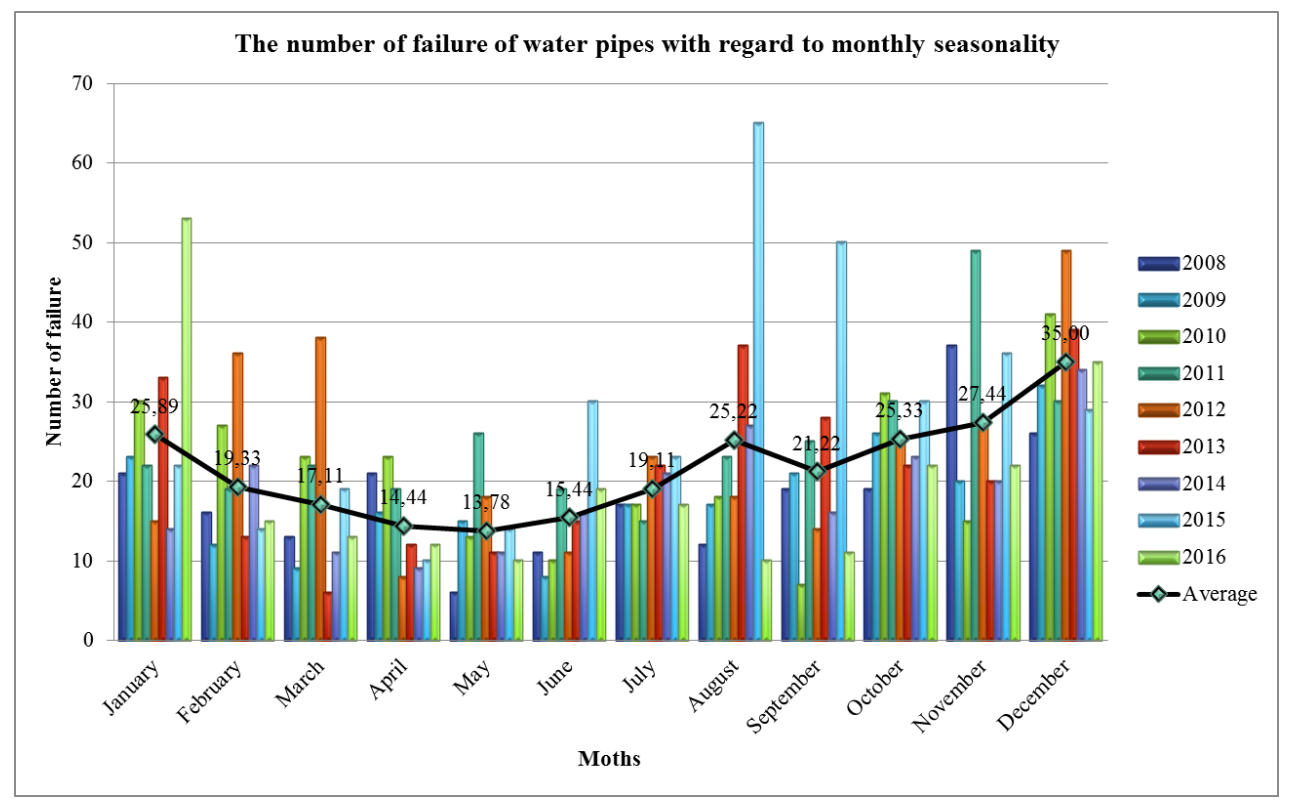

Fig. 2. Failure of water pipes with regard to monthly seasonality.

Figure 3 shows the relative and absolute seasonal fluctuations of number of failures on the water supply network, while in figure 4 absolute seasonal variations. 


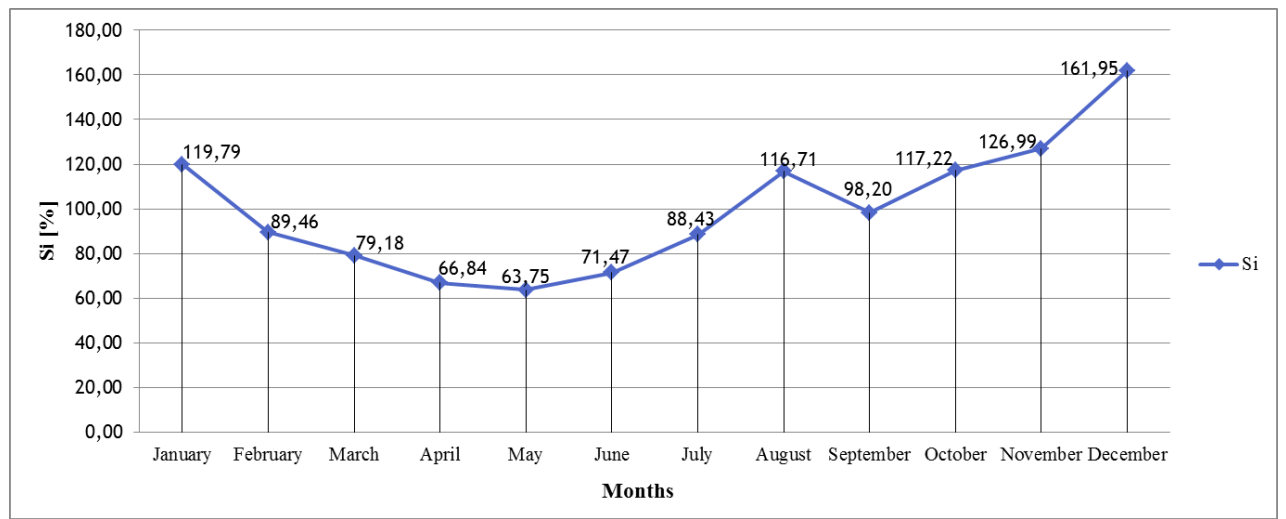

Fig. 3. Relative seasonal fluctuations of the number of failures on water supply network and house connections.

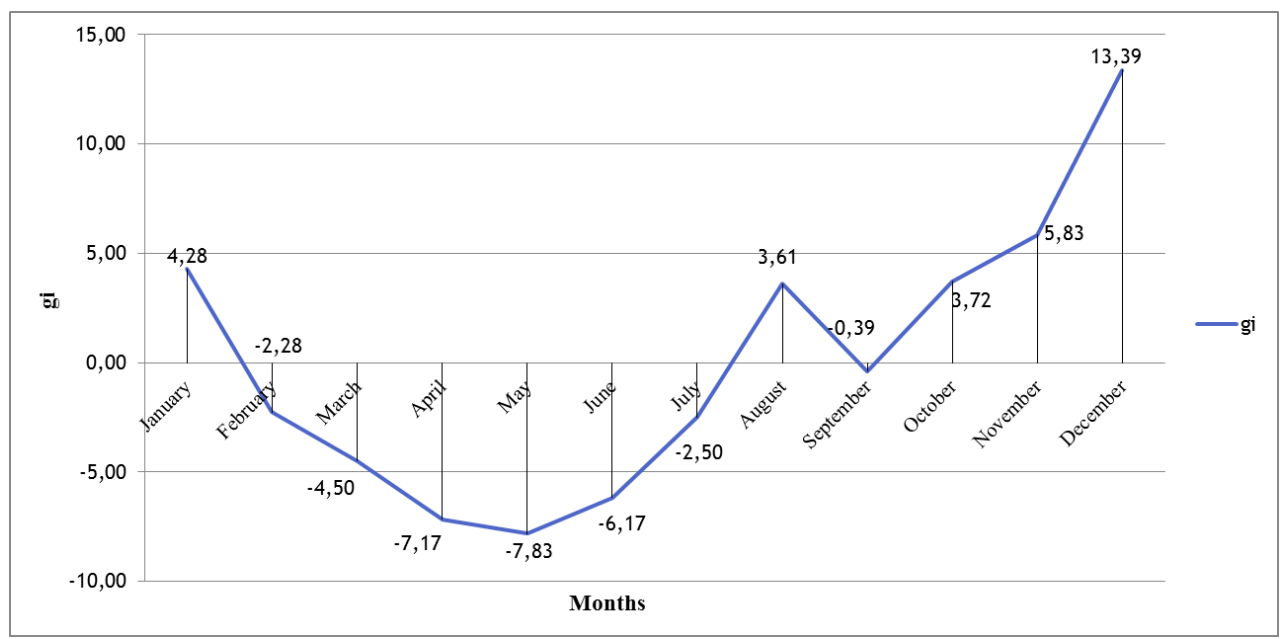

Fig. 4. Absolute seasonal fluctuations of the number of failures on the water supply network and house connections.

The seasonal index $\mathrm{S}_{\mathrm{i}}$ defines the magnitude of changes in relation to the average monthly number of failures $\bar{y}=\frac{259.33}{12}=21.61$ failure/month $(100 \%)$.

The absolute levels of seasonal fluctuations $\left(g_{i}\right)$ determine the number of failures lower/higher in relation to the monthly number of failures.

To determine seasonal variations, the seasonal index $S_{i}$ is determined for homonymous periods, which may be, for example, months, seasons or other type of period. The sum of monthly seasonal indices $\Sigma S_{i}$ has reached the required value of 1200 , which proves the correctness of calculations (according to the formula (1) the sum of $S_{i}$ divided by 100 must give the number of months in the year -12).

\section{Conclusions}

Failures in the water supply network are a fundamental problem of the functioning of water supply systems all over the world. In order to ensure the recipient the reliability of water 
supply, one should, first of all, try to minimize interruptions in water delivery by quick location of failures and successive replacement of old water pipes, which are the main source of water supply failures. In order to reduce the failure rate and related costs, each water supply network should undergo gradual modernization in order to improve the reliability of water distribution, which will cause a gradual decrease in the failure rate and increase in the satisfaction of water consumers. The presented analysis showed a declining trend in the number of failures in the years discussed. A characteristic seasonality of the number of failures, with high values in the autumn and winter months and a lower failure rate in the spring and summer months, was observed. Based on the performed analysis, it was found that the higher number of failures than the average value 21.61 was in August, October, November, December and January. The maximum value was recorded in December, $161.95 \%$, while the lowest number of exceedances was recorded in May, lower than the average value by $36.25 \%$. The absolute seasonal fluctuations show the number of failures relative to the monthly average. In the month of May the absolute seasonal fluctuations reached the smallest value $\left(g_{i}=-7.83\right.$ failures), while in the month of December they reached their maximum value ( $g_{i}=13.39$ failures).

\section{References}

1. Ustawa z dnia 26 kwietnia 2007 r. o zarządzaniu kryzysowym (Dz.U. 2007 nr 89 poz. 590) z późniejszymi zmianami (2007)

2. Ustawa $z$ dnia 7 czerwca 2001 r. o zbiorowym zaopatrzeniu w wodę i zbiorowym odprowadzaniu ścieków (Dz.U. 2001 nr 72 poz. 747) z późniejszymi zmianami (2001)

3. Rozporządzenie Ministra Zdrowia z dnia 13 listopada 2015 r. w sprawie wymagań dotyczących jakości wody przeznaczonej do spożycia przez ludzi (Dz. U. z dnia 27.11.2015 r. poz.1989) (2015)

4. WHO, Guidelines for Drinking-water Quality (Fourth Edition, Geneva, 1, 2011)

5. WHO, Water Quality and Health Strategy 2013-2020 (Geneva, 2013)

6. J. Rak, M. Kwietniewski, D. Kowalski, B. Tchórzewska-Cieślak, I. Zimoch, J. Bajer, R. Iwanejko, K. Miszta-Kruk, A. Studzieński, K. Boryczko, K. Pietrucha-Urbanik, I. Piegdoń, Metody oceny niezawodności i bezpieczeństwa dostawy wody do odbiorców (Rzeszów, 2013)

7. J. Rak, Wybrane zagadnienia niezawodności i bezpieczeństwa $w$ zaopatrzeniu $w$ wode (Rzeszów, 2008)

8. A. Wieczysty, R. Iwanejko, T. Lubowiecka, J. Rak, Ekoinżynieria 4, 7-12 (1995)

9. J. Królikowska, Niezawodność funkcjonowania i bezpieczeństwa sieci kanalizacyjnej (Kraków, 2011)

10. I. Zimoch, Zintegrowana metoda analizy niezawodności funkcjonowania i bezpieczeństwa systemów zaopatrzenia $w$ wode (Gliwice, 2011)

11. B. Tchórzewska Cieślak, Niezawodność i bezpieczeństwo systemów komunalnych na przyktadzie systemu zaopatrzenia w wodę (Rzeszów, 2008)

12. M. Kwietniewski, M. Roman, H. Kłoss-Trębaczkiewicz, Niezawodność wodociagów i kanalizacji (Warszawa, 1993)

13. M. Kwietniewski, J. Rak, Niezawodność infrastruktury wodociagowej i kanalizacyjnej w Polsce (Komitet Inżynierii Lądowej i Wodnej PAN, Warszawa, 2010)

14. B. Tchórzewska Cieślak, K. Boryczko, I. Piegdoń, Safety and Reliability: Methodology and Applications, London, 1473-1480 (2014) 
15. I. Piegdoń, B. Tchórzewska-Cieślak, D. Szpak, Environmental Engineering V, London, 7-14 (2017)

16. B. Tchórzewska Cieślak, K. Boryczko, M. Eid, Advances in Safety, Reliability and Risk Management, London, 2492-2499 (2012)

17. J. Rak, B. Tchórzewska-Cieślak, Gaz, Woda i Technika Sanitarna 11, 49-51 (2005)

18. F. Piechurski, Wodociągi Kanalizacja, 1, 23, 16-17 (2006)

19. H. Hotloś, Ilościowa ocena wpływu wybranych czynników na parametry i koszty eksploatacyjne sieci wodociagowych (Prace Instytutu Inżynierii Ochrony Środowiska Politechniki Wrocławskiej, Wrocław, 2007)

20. A.O. Lambert, Water Science and Technology: Water Supply 2, 4 (2002)

21. R. Sadiq, Y. Kleiner, B. Rajani, Journal of Water Supply Research and Technology: AQUA, 53, 4, 241-261 (2004)

22. J. Pawełek, M. Wojdyna, Gaz, Woda i Technika Sanitarna 2, 49-54 (2001)

23. M. Kwietniewski, Awarie Budowlane, 127-140 (2011)

24. D. Szpak, B. Tchórzewska-Cieślak, CHEMIK 68, 10, 862-867 (2014)

25. B. Tchórzewska-Cieślak, International Journal of Materials \& Structural Reliability 6, 1, 121-131 (2008)

26. D. Szpak, B. Tchórzewska-Cieślak, Dependability Engineering and Complex Systems. Advances in Intelligent Systems and Computing 470, 479-489 (2016)

27. K. Pietrucha-Urbanik, A. Studziński, Eksploatacja i Niezawodność - Maintenance and Reliability 19, 3, 317-323 (2017)

28. P. Dohnalik, P.Wytrwał, Gaz, Woda i Technika Sanitarna 11, 31-33 (2005)

29. H. Hotloś, Gaz, Woda i Technika Sanitarna 5, 180-184 (1999) 